\title{
PALEOBATHYMETRY ANALYSIS OF LIMESTONE IN BONGOMEME REGION BASED ON CONTENT OF BENTHIC FORAMINIFERA FOSSIL, GORONTALO DISTRICT, INDONESIA
}

\author{
Aang Panji Permana* ** Subagyo Pramumijoyo** and Akmaluddin** \\ *Department of Geological Engineering, Universitas Negeri Gorontalo, \\ Gorontalo, Indonesia \\ ** Department of Geological Engineering, Universitas Gadjah Mada, \\ Yogyakarta, Indonesia
}

•Corresponding author: bagyo@ugm.ac.id

Received Date: 29 June 2019, Accepted Date: 08 December 2019, Published Date: 24 June 2020

\begin{abstract}
The location of the study area is surging hills in Bongomene area, Gorontalo, Indonesia. In this study, a geological survey and sampling were taken, and then an analysis of the content of benthic foraminifera was performed in each sample. The study aims to discover the species of benthic foraminifera fossils and to determine the paleobathymetry to the studied regions. The results of the analysis contained seven fossils species, namely Ammomassilina alveoliniformis, Stelligerum astrononion, Haynesia germanica, Nonion fabum, Praeglobobulimina ovata, Rhabdammina discreata and Saccorhiza ramosa. Based on the content of benthic foraminifera fossils, paleobathymetry is determined as Middle Shelf to Outer Shelf in Bongomeme 1, while in Bongomeme 2 and 3 is Middle Shelf.
\end{abstract}

Keywords: Benthic foraminifera, Bongomeme, Fossils, Limestone, Paleobathymetry.

\section{INTRODUCTION}

Limestone is the sediment consists mostly of structured fragments produced by various types of organisms with specific ecological requirements (Meteu-Vicens et al., 2008) and commonly occurs and has wide distribution in the carbonate platform. The carbonate platform is characterized by the reestablishment of shallow seawater benthic communities (Berggren and Prothero, 1992; Ivany et al., 2000; Prothero, 2003).

Foraminifera has proven useful in reconstructing as is palaeoenvironmental in shallow seawater environments (Mendes et al., 2004; Murray, 2006). The most critical control in the distribution of benthic foraminiferal is food availability and dissolved oxygen concentration 
Paleobathymetry analysis of limestone in Bongomeme

(Jorissen et al., 1995; De Rijk et al., 1999, 2000; Murray, 2001). Analysis of paleobathymetry based on foraminifera assemblages was carried out on Pliocene aged rocks in western Sahal with semi-quantitative reconstruction (Herkat and Ladjal, 2013).

Micropaleontology is a systematic study of microfossils, their morphology, classification and environmental and stratigraphic significance. For practical purposes, microfossils are any fossils, usually small, with the characteristic of which is best studied through a microscope. These include heterogeneous groups of fossils of organisms that are generally microscopic, for instance, foraminifera, ostracoda and radiolaria (Saraswati and Srinavasan, 2016).

Based on the previous study, the study area is included in Reef Limestone Formation (QI), which consists of reef limestone. In addition to this area, the Reef limestone units are also found in Tanjung Kramat Region. Petrology analysis of limestone shows the name of the limestone is calcirudite or floatstone (Bachri et al., 1997; Embry and Klovan, 1971; Grabau, 1905; Permana and Eraku, 2017; Permana, 2018).

This research aims to identify the species of benthic foraminifera fossil containing in Bongomeme limestone and to determine the paleobathymetry.

\section{MATERIALS AND METHODS}

This research located in Bongomeme Region of Gorontalo District, Indonesia. Western area of Limboto Lake which located at geomorphology of surging hills. The study area divided into three location, that is Bongomeme (1) $\left(00^{\circ} 35^{\prime} 29.18^{\prime \prime} \mathrm{N} ; 122^{\circ} 52^{\prime} 45.82^{\prime \prime} \mathrm{E}\right)$, Bongomeme (2) $\left(00^{\circ} 35^{\prime} 34.680^{\prime \prime} \mathrm{N} ; 122^{\circ} 52^{\prime} 50.92^{\prime \prime} \mathrm{E}\right)$ and Bongomeme (3) (00 36 41.260" $\mathrm{N} ; 122^{\circ} 50^{\prime} 44.34^{\prime \prime}$ E) (Map 1). The stratigraphic section of this study can be seen in Diagram (1).

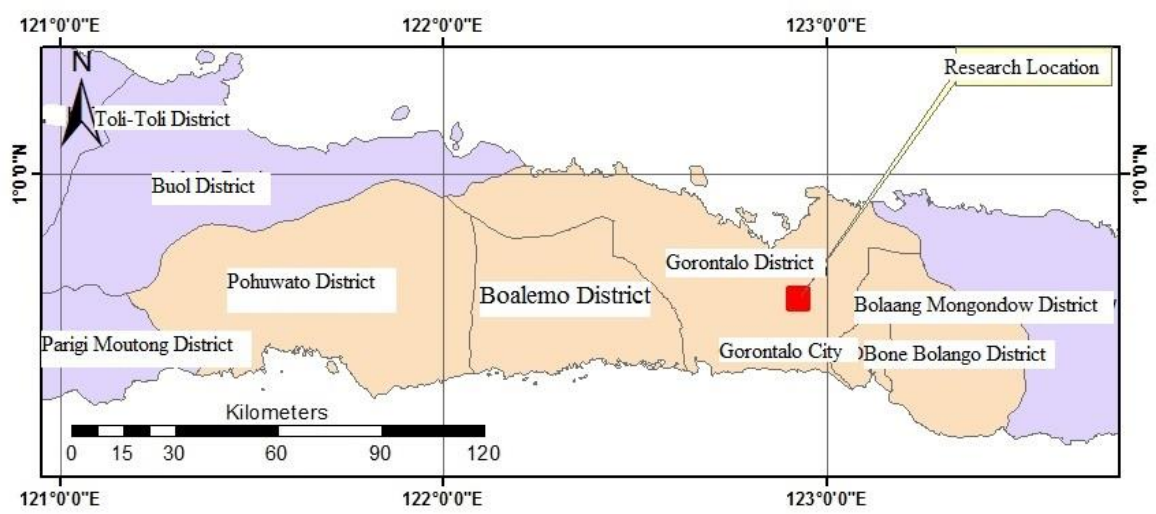

Map (1): Location map to the studied area; that's located in Bongomeme Region, Indonesia. 


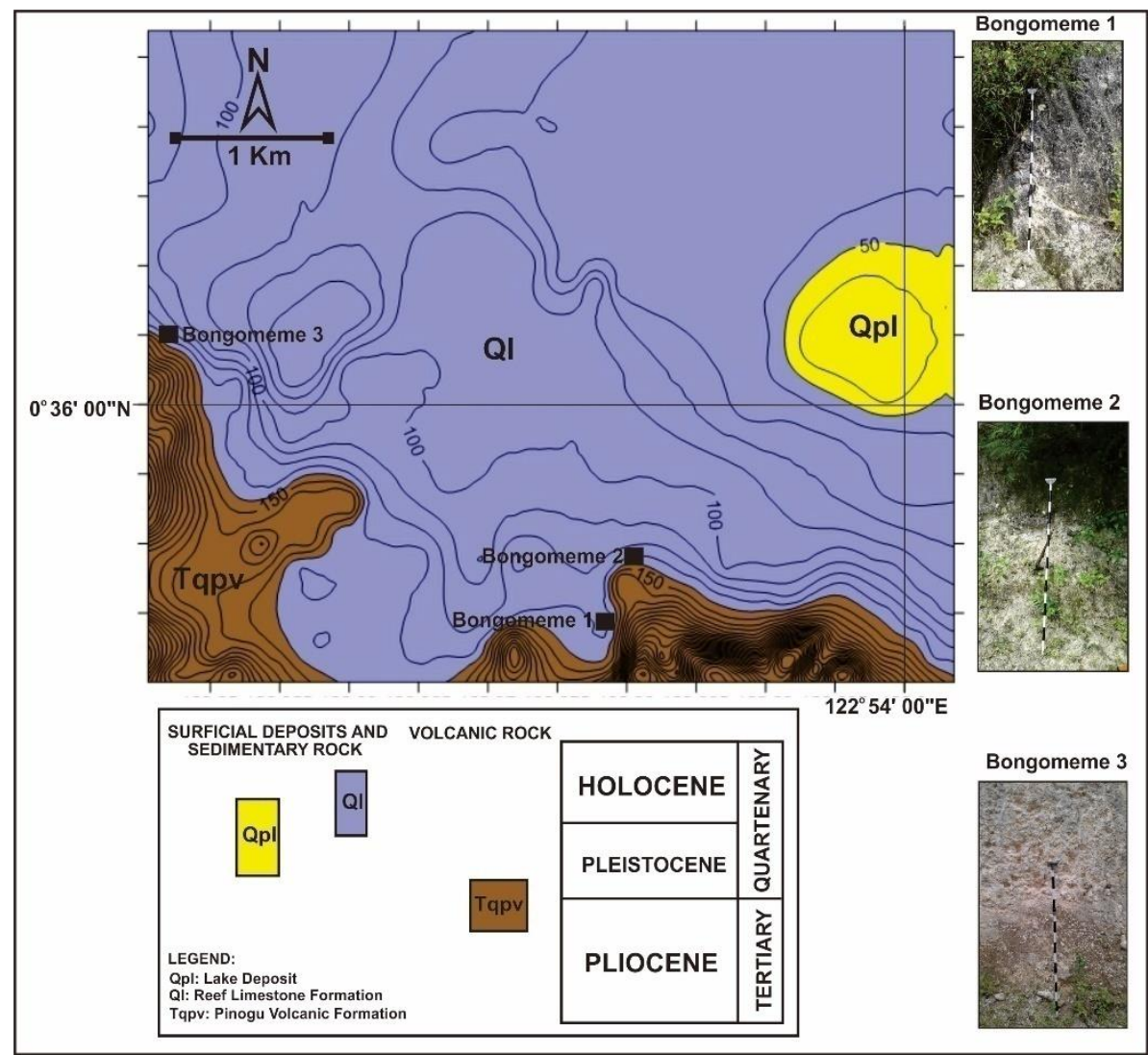

Diagram (1): The stratigraphic sections of this study, divided into three locations that is Bongomeme 1, Bongomeme 2 and Bongomeme 3. The geological map is according to Bachri et al (1997).

Material or research materials of samples are limestone containing benthic foraminifera fossils. The research method consisted of two stages, namely field survey and micropaleontological analysis. The field survey carried out is geological survey and determination of samples that were feasible to be analyzed and descriptions of petrology. The micropaleontological analysis was carried out to determine paleobathymetry based on the content of benthic foraminifera fossils (Ghosh and Sarkar, 2013; Martins et al., 2015; Roozpeykar and Moghaddam, 2016). Fossils identification is using by the Olympus SZ61 binocular microscope.

In this study, preparations were carried out on samples with a weight of $100 \mathrm{gr}$ on each sample. To prepare the benthic foraminifera fossil sample, a solution of 30-50\% hydrogen peroxide $\left(\mathrm{H}_{2} \mathrm{O}_{2}\right)$, blue methyl solution, 100 mesh sized filter, electric oven sample dryer and digital scales were used (Kadar, 1986). 
Paleobathymetry analysis of limestone in Bongomeme

Identification of benthic foraminifera fossil for the determination of paleobathymetry refers to the classification of Tipsword et al (1966) and Jones (1994). Ranking of the determination of paleobathymetry based on the depth of habitat of each benthic foraminifera species. Division of depth based on the environmental intervals of each foraminifera species. Each identified species is calculated for its abundance in each sample. The amount of abundance of one species uses the classification of Kadar (1986).

\section{RESULTS AND DISCUSSION}

Geological surveys in the research area indicate that the main constituents are limestone. Based on Hand specimen description, the limestone has white color, medium sorting, floating grains in the matrix (component supported) and bedding structures with an abundance of $>2$ $\mathrm{mm}$ granules of $15 \%$. The compositions are large benthic foraminifera, coral fragments, and opaque minerals as a fragment matrix in the form of micrite. Based on the description of the petrology, the names calcirudite or coralline rudstone. Besides, based on the content of coral fragment, it interpreted that the limestone in the Bongomeme area is a Reefal limestone, which forms around (both near or little far) from the reef build-up. The chart of facies distribution and paleobathymetry of this study can be seen in Diagram (2). 
Permana et al.

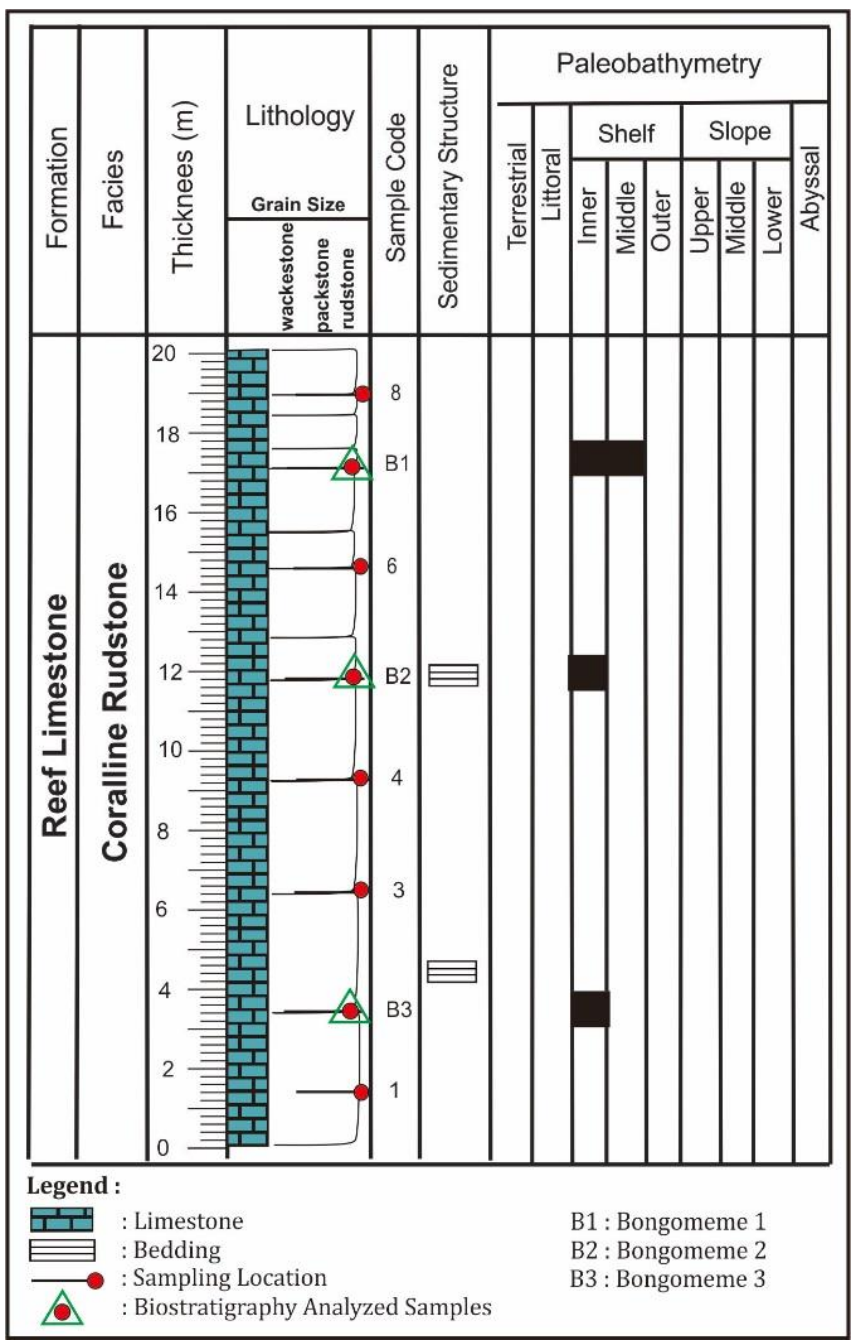

Diagram (2): Chart of facies distribution and paleobathymetry in research location (Bongomeme).

The results of geological survey and Hand specimen description which interpreted that samples of reef limestone contained large fossils of foraminifera, samples were taken for micropaleontological analysis.

The results of micropaleontological analysis shows that the number of benthic foraminifera species is varies. Bongomeme (1) there are three species of benthic foraminifera fossils namely Haynesia germanica (Ehrenberg, 1840), Praeglobobulimina ovata (d'Orbigny, 1846) and Rhabdammina discreata (Brady, 1881). Bongomeme (2) there are six species of benthic 
Paleobathymetry analysis of limestone in Bongomeme

foraminifera fossils namely Ammomassilina alveoliniformis (Millett, 1898), Haynesia germanica (Ehrenberg, 1840), Nonion fabum (Fichtel and Moll, 1798), Praeglobobulimina ovata (d'Orbigny, 1846), Rhabdammina discreata (Brady, 1881) and Saccorhiza ramosa (Brady, 1879). Bongomeme (3) there are four species of benthic foraminifera fossils namely Ammomassilina alveoliniformis (Millett, 1898), Astrononion stelligerum (d'Orbigny, 1839), Lamellodiscorbis (Loeblich and Tappan, 1987) and Rhabdammina discreata (Brady, 1881). Seven types of fossil species can be seen in Plate (1).

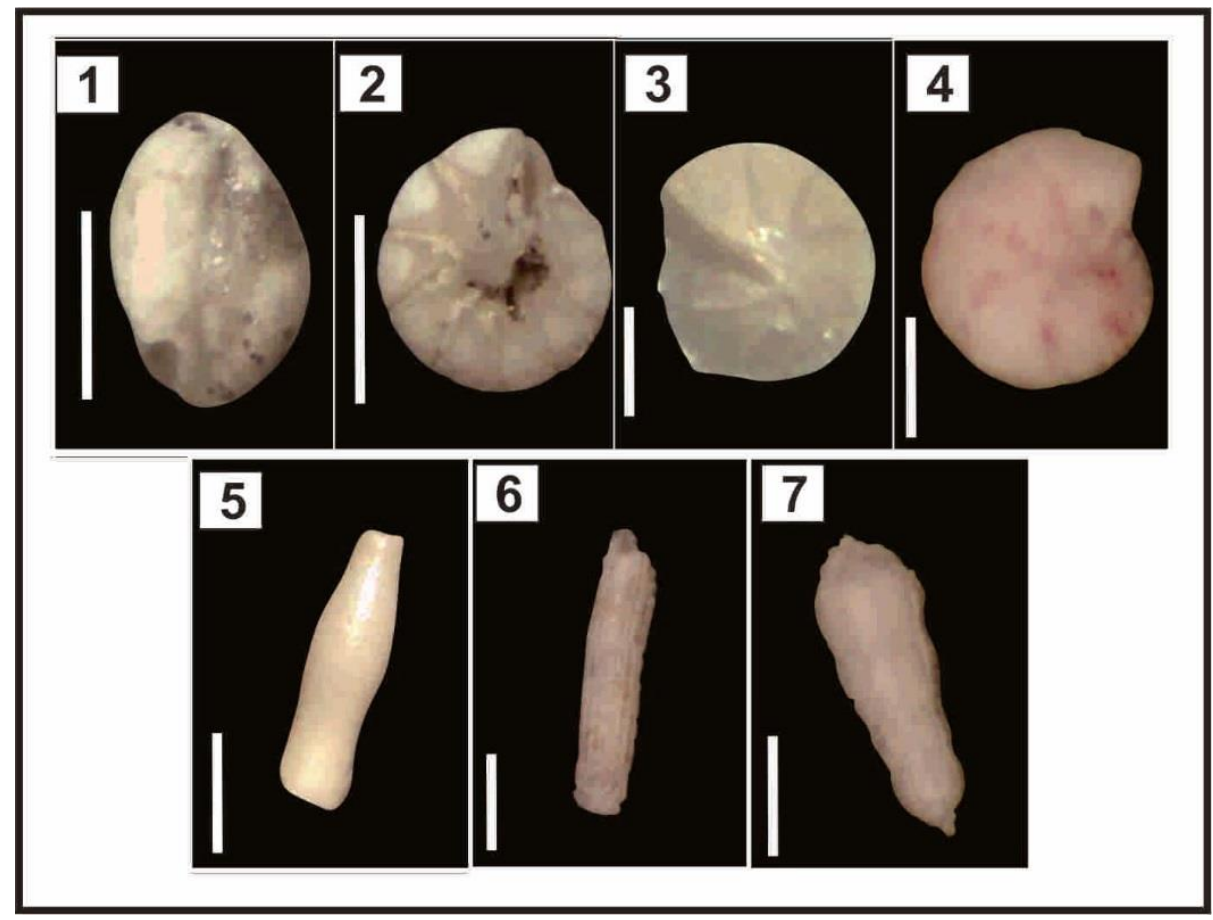

Plate (1): Seven species of benthic foraminifera fossils found in research location; (1) Ammomassilina alveoliniformis, (2) Astrononion stelligerum, (3) Haynesia germanica, (4) Nonion fabum, (5) Praeglobobulimina ovata, (6) Rhabdammina discreata, (7) Saccorhiza ramosa (scale size: $100 \mathrm{um}$ ).

Complete classification of benthic foraminifera fossils in three different research location can be seen in Table (1) 
Permana et al.

Table (1): Classification of Foraminifera Benthic Fossil Containment in Bongomeme Region (Hayward et al., 2018 a, b, c, d, e).

\begin{tabular}{cccccccc}
\hline Classification & Species 1 & Species 2 & Species 3 & Species 4 & Species 5 & Species 6 & Species 7 \\
\hline Phylum & Foraminifera & Foraminifera & Foraminifera & Foraminifera & Foraminifera & Foraminifera & Foraminifera \\
Class & Tubothalamea & Globothalamea & Globothalamea & Globothalamea & Globothalamea & Monothalamea & Monothalamea \\
Order & Miliolida & Rotaliida & Rotaliida & Rotaliida & Rotaliida & Astrorhizida & Astrorhizida \\
Suborder & Miliolina & Rotaliina & Rotaliina & Rotaliina & Rotaliina & Astrorhizina & Hippocrepinina \\
Superfamily & Milioloidea & Nonionoidea & Rotalioidea & Nonionoidea & Buliminoidea & Astrorhizoidea & Hippocrepinoidea \\
Family & Hauerinidae & Nonionidae & Haynesinidae & Nonionidae & Buliminidae & Rhabdamminidae & Hyperamminidae \\
Subfamily & Siphonapertinae & Astrononioninae & & Nonioninae & & Rhabdammininae & Saccorhizinae \\
Genus & Ammomassilina & Astrononion & Haynesina & Nonion & Praeglobobulimina & Rhabdammina & Saccorhiza \\
Species & alveoliniformis & stelligerum & germanica & fabum & ovata & discreta & ramose \\
& (Millett, 1898) & (d'Orbigny, & (Ehrenberg, & (Fichtel and & (d'Orbigny, 1846) & (Brady, & (Brady, \\
& & $1839)$ & $1840)$ & Moll, 1798) & & 1881) & $1879)$ \\
\hline
\end{tabular}

The total abundance of each fossil species in each location according to (Kadar, 1986) can be seen in Table (2) (Bongomeme 1), Table (3) (Bongomeme 2) and Table (4) (Bongomeme $3)$.

Table (2): The abundance of each benthic foraminifera fossils species in Bongomeme 1 .

\begin{tabular}{ccc}
\hline Species & Total & Abundance \\
\hline Haynesia germanica & 1 & Very Rare (VR) \\
Praeglobobulimina ovata & 2 & Rare (R) \\
Rhabdammina discreta & 9 & Frequent (F) \\
\hline
\end{tabular}

Table (3): The abundance of each benthic foraminifera fossils species in Bongomeme 2.

\begin{tabular}{ccc}
\hline Species & Total & Abundance \\
\hline Ammomassilina alveoliniformis & 2 & Rare (R) \\
Haynesia germanica & 1 & Very Rare (VR) \\
Nonion fabum & 1 & Very Rare (VR) \\
Praeglobobulimina ovata & 3 & Rare (R) \\
Rhabdammina discreata & 5 & Rare (R) \\
Saccorhiza ramosa & 3 & Rare (R) \\
\hline
\end{tabular}

Table (4): The abundance of each benthic foraminifera fossils species in Bongomeme 3.

\begin{tabular}{ccc}
\hline Species & Total & Abundance \\
\hline Ammomassilina alveoliniformis & 1 & Very Rare (VR) \\
Astrononion stelligerum & 1 & Very Rare (VR) \\
Lamellodiscorbis & 1 & Very Rare (VR) \\
Rhabdammina discreta & 9 & Frequent (F) \\
\hline
\end{tabular}


Paleobathymetry analysis of limestone in Bongomeme

Table (5): Paleobathymetry Analysis of Bongomeme 1.

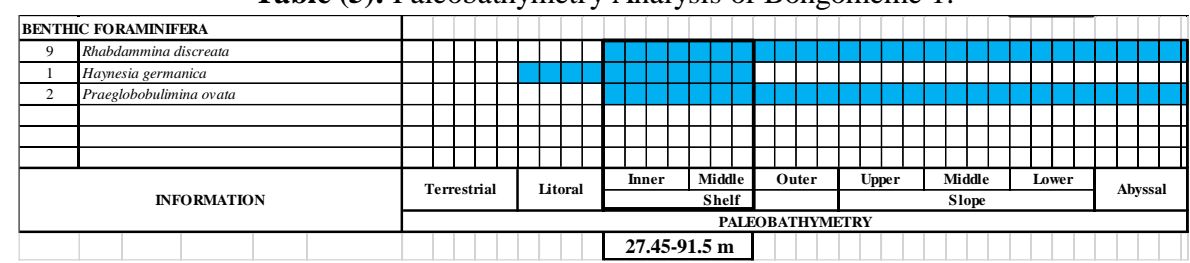

Table (6): Paleobathymetry Analysis of Bongomeme 2.

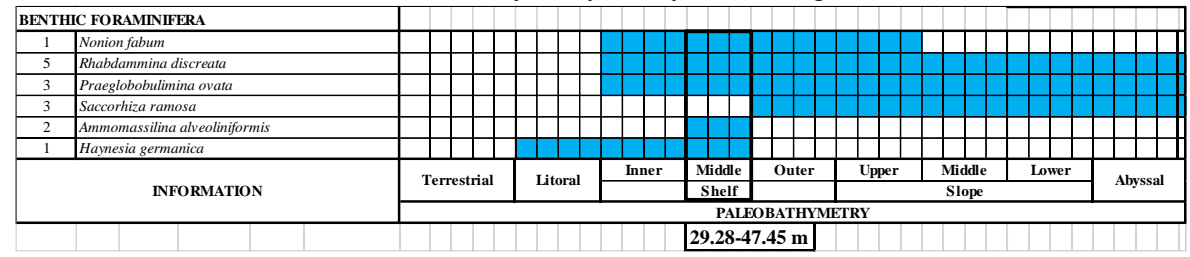

Table (7): Paleobathymetry Analysis of Bongomeme 3.

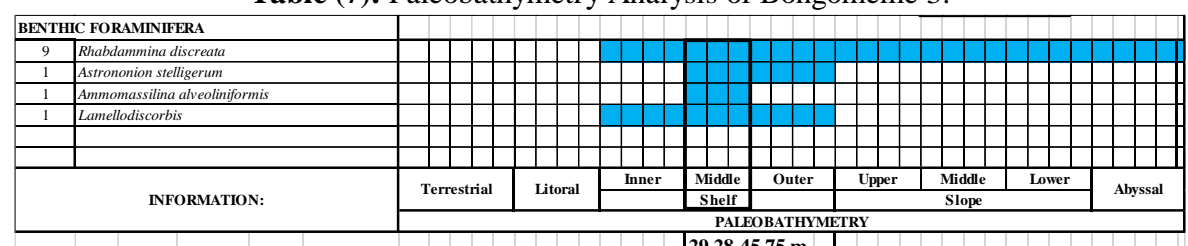

$29.28-45.75 \mathrm{~m}$

Based on the research results, there are seven species of benthic foraminifera fossils; therefore, paleobathymetry analysis could be carried out. The analysis was carried out by overlaying the presence of species of benthic foraminifera fossils while it was life. Analysis of paleobathymetry for each location based on Tipsword et al (1966) and Jones (1994) can be seen in Table (5) (Bongomeme 1), Table (6) (Bongomeme 2) and Table (7) (Bongomeme 3). The results of the analysis of paleobathymetry shows that paleobathymetry of the limestone Bongomeme 1 area is Middle Shelf - Outer Shelf (27.45-91.5 meters)(Jones, 1994). Paleobathymetry of the limestone Bongomeme 2 area is Middle Shelf (29.28 - 47.45 meters) (Jones, 1994) and paleobathymetry of the limestone in Bongomeme 3 area is Middle Shelf (29.28 - 45.75 meters) (Jones, 1994).

The presence of Ammomassilina alveoliniformis species which belongs to the suborder Milliolina indicates the lagoon environment. To prove this, make a comparison of the Rotaliina - Textulariina - Miliolina suborder uses a triangle diagram of Armstrong and Brasier (2005). A comparison of the Rotaliina-Textulariina-Miliolina suborder can be seen in Table (8), and the plotting of triangular diagram of Armstrong and Brasier (2005) can be seen in Diagram (3).

Based on this analysis, it is known that limestone at the location includes hypersaline lagoons, which are formed under hypersaline sea water conditions due to semi-closed water 
Permana et al.

circulation which is likely caused by a barrier. If we looking at the composition of limestone that composed by coral fragments, it is interpreted that the barrier is reef build-up.

Table (8): Comparison of Rotaliina - Textulariina - Miliolina suborder.

\begin{tabular}{cccccccc}
\hline \multirow{2}{*}{ Location } & \multicolumn{2}{c}{ Miliolina } & \multicolumn{2}{c}{ Rotaliina } & \multicolumn{2}{c}{ Textulariina } & \multirow{2}{*}{ Total } \\
\cline { 2 - 7 } & Specimen & $\%$ & Specimen & $\%$ & Specimen & $\%$ & \\
\hline Bongomeme-1 & 0 & 0,0 & 3 & 100,0 & 0 & 0,0 & 3 \\
\hline Bongomeme-2 & 2 & 28,6 & 5 & 71,4 & 0 & 0,0 & 7 \\
\hline Bongomeme-3 & 1 & 50,0 & 1 & 50,0 & 0 & 0,0 & 2 \\
\hline
\end{tabular}

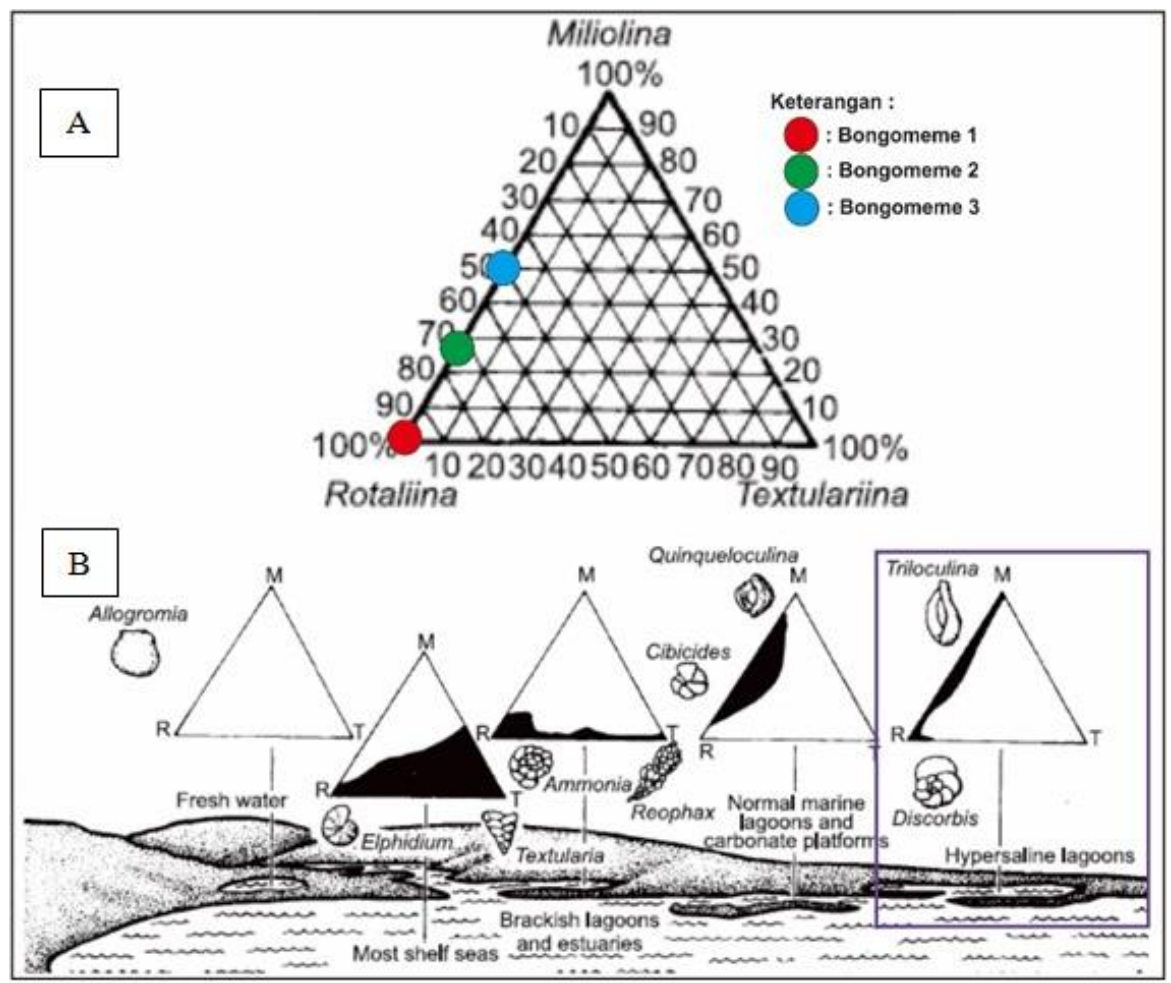

Diagram (3): Comparison of the Rotaliina - Textulariina - Miliolina suborder uses a triangle diagram of Armstrong and Brasier (2005); (A) Plotting of comparison of Rotaliina - Textulariina - Miliolina, suborder, (B) The interpretation of lagoonal condition environment.

Paleobathymetry analysis of the research area at the time of limestone formation was deposited based on the content of benthic foraminifera fossils, finally could answer the research objectives. The Bongomeme area of Gorontalo Regency, which is currently formed by elevations above sea level of 49 meters to hundreds of meters, is based on the history of 
Paleobathymetry analysis of limestone in Bongomeme

limestone formation under the marine. The location of the research was experiencing elevation from the shallow marine Middle Neritic to now land. This fact is strengthened by data on the presence of benthic foraminifera fossils which characterize the marine environment, with hypersaline lagoon condition

\section{CONCLUSION}

Based on the results and discussion, some important conclusions can be mentioned. The Bongomeme area of Gorontalo Regency consisting by reefal limestones containing benthic foraminifera fossil and coral fragments.

The results of micropaleontological analysis have showed that there are seven species of benthic foraminifera fossils namely Ammomassilina alveoliniformis (Millett, 1898), Astrononion stelligerum (d'Orbigny, 1839), Haynesia germanica (Ehrenberg, 1840), Nonion fabum (Fichtel and Moll, 1798), Praeglobobulimina ovata (d'Orbigny, 1846), Rhabdammina discreata (Brady, 1881) and Saccorhiza ramosa (Brady, 1879).

The analysis of paleobathimetry has revealed that the research area was previously a shallow marine environment, which the paleobathymetry of the limestone Bongomeme 1 area. The result of the analysis of paleobathymetry shows that paleobathymetry of the limestone Bongomeme 1 area is Middle Shelf - Outer Shelf (27.45-91.5 meters). Paleobathymetry of the limestone Bongomeme 2 area is Middle Shelf (29.28 - 47.45 meters) and paleobathymetry of the limestone in Bongomeme 3 area is Middle Shelf (29.28 - 45.75 meters).

\section{LITERATURE CITED}

Armstrong, H. A. and Brasier, M. D. 2005. Microfossils. $2^{\text {nd }}$ edition, Blackwell Publishing, Oxford, United Kingdom, 304 pp.

Bachri, S., Partoyo, E., Bawono, S.S., Sukarna, D., Surono. and Supandjono, J. B. 1997. Regional Geology of Gorontalo, North Sulawesi. Collection of Research and Mapping Results Papers Centre for Geological Research and Development : 18-30. (Indonesia version).

Berggren, W.A. and Prothero, D. R. 1992. Eocene-Oligocene climatic and biotic evolution: an overview. In: Prothero, D. R., Berggren, W.A. (Eds.), Eocene- Oligocene Climatic and Biotic Evolution. Princeton University Press, Princeton, p 1-28.

De Rijk, S., Troelstra, S. R. and Rohling, E. J. 1999. Benthic foraminiferal distribution in the Mediterranean Sea. Journal of Foraminiferal Research, 29 : 93-100.

De Rijk, S., Jorissen, F. J., Rohling, E. J. and Troelstra, S. R. 2000. Organic flux control on bathymetric zonation of Mediterranean benthic foraminifera. Marine Micropaleontology, 40: 151-166. 
Permana et al.

Embry, A. F. and Klovan, J. E. 1971. A Late Devonian reef tract on northeastern Banks Island, NWT. Bulletin of Canadian Petroleum Geology, 19 : 730-781.

Ghosh, A. K. and Sarkar, S. 2013. Facies analysis and paleoenvironmental interpretation of Piacenzian carbonate deposits from the Guitar Formation of Car Nicobar Island, India. Geoscience Frontiers, 4 : 755-764.

Grabau. 1905. Physical Character and History of some New York Formations. Science, 22 : 528-535.

Hayward, B. W, Le Coze, F. and Gross, O. 2018a. World Foraminifera Database. Ammomassilina alveoliniformis (Millett, 1898). Accessed at: http://www.marinespecies.org/foraminifera/aphia.php?p=taxdetails\&id=112539 on 2019-02-26.

Hayward, B. W, Le Coze, F. and Gross, O. 2018b. World Foraminifera Database. Astrononion stelligerum (d'Orbigny, 1839). Accessed at: http://www.marinespecies.org/foraminifera/aphia.php?p=taxdetails\&id=113552 on 2019-02-26.

Hayward, B.W, Le Coze, F. and Gross, O. 2018c. World Foraminifera Database. Haynesina germanica (Ehrenberg, 1840). Accessed at: http://www.marinespecies.org/foraminifera/aphia.php?p=taxdetails\&id=113294 on 2019-02-26.

Hayward, B. W, Le Coze, F. and Gross, O. 2018d. World Foraminifera Database. Nonion fabum $\quad$ (Fichtel Moll, 1798). Accessed at: http://www.marinespecies.org/foraminifera/aphia.php?p=taxdetails\&id=484789 on 2019-02-26.

Hayward, B. W, Le Coze, F. and Gross, O. 2018e. World Foraminifera Database. Rhabdammina discreta Brady, 1881. Accessed at: http://www.marinespecies.org/foraminifera/aphia.php?p=taxdetails\&id=113900 on 2019-02-26.

Herkat, M. and Ladjal, A. 2013. Paleobathymetry of foraminiferal assemblages from the Pliocene of the Western Sahel (North-Algeria). Palaeogeography, Palaeoclimatology, Palaeoecology, 374 : 144-163.

Ivany, L. C., Patterson, W. P. and Lohmann, K. C. 2000. Cooler winters as a possible cause of mass extinctions at the Eocene/Oligocene boundary. Nature, $407: 887-890$.

Jones, R. W. 1994. The challenger foraminifera. Oxford, Oxford University Press, 149 pp. 
Paleobathymetry analysis of limestone in Bongomeme

Jorissen, F. J., de Stigter, H. C. and Widmark, J. G. V. 1995. A conceptual model explaining benthic foraminiferal microhabitats. Marine Micropaleontology, 26 : 3-15.

Kadar, D. 1986. Neogene Planktonic Foraminiferal Biostratigraphy of the South Central Java area, Indonesia. Geology Research and Development Centre, Special Publication, 5: 1103.

Loeblich, A. R. and Tappan, H. 1987. Foraminiferal Genera and their Classification. Van Nostrand Reinhold Company, New York, 970 pp.

Martins, M. V. A., Silva, F., Laut, L. L. M., Frontalini, F., Clemente, I. M. M .M., Miranda, P., Figueira, R., Sousa, S. H. M. and Dias, J. A. M. 2015. Response of benthic foraminifera to organic matter quantity and quality and bioavailable concentrations of metals in Aveiro Lagoon (Portugal), PLoS ONE, 10(2) : 1-23.

Mateu-Vicens, G., Hallock, P. and Brandano, M. 2008. A depositional model and paleoecological reconstruction of the lower Tortonian distally steepened ramp of Menorca (Balearic Islands, Spain). Palaios, 23 : 465-481.

Mendes, I., Gonzaleza, R., Diasb, J. M. A., Loboa, F. and Martinsc, V. 2004. Factors influencing recent benthic foraminifera distribution on the Guadiana shelf (Southwestern Iberia). Marine Micropaleontology, 51 : 171-192.

Murray, J. W. 2001. The niche of benthic foraminifera, critical thresholds and proxies. Marine Micropaleontology, $41: 1-7$.

Murray, J. W. 2006. Ecology and Applications of Benthic Foraminifera. Cambridge University Press, New York, 426 pp.

Permana, A. P. 2018. Potential of Gorontalo reef limestone as industrial material based on XRF geochemistry analysis. EnviroScienteae, 14 (3): 174-179. (Indonesia version)

Permana, A. P. and Eraku, S. S. 2017. Stratigraphic analysis of Tanjung Kramat Region, Hulonthalangi District, Gorontalo City. Geomine Journal, 5(1) : 1-6. (Indonesia version)

Prothero, D. R. 2003. Pacific coast Eocene-Oligocene marine chronostratigraphy: a review and an update. In: Prothero, D. R., Ivany, L. C. and Nesbitt, E. A. (eds.), From Greenhouse to Icehouse: The Marine Eocene-Oligocene Transition. Columbia University Press, New York, 1-13.

Roozpeykar, A. and Moghaddam, I.M. 2016. Benthic foraminifera as biostratigraphical and paleoecological indicators: An example from Oligo-Miocene deposits in the SW of Zagros basin, Iran. Geoscience Frontiers, 7 : 125-140. 


\section{Permana et al.}

Saraswati, P. K. and Srinivasan, M. S. 2016. Micropaleontology principles and applications. Springer Internation Publishing Switzerland, 224 pp.

Tipsword, H. L. Setzer, F. M. and Smith, L. F. 1966. Interpretation of depositional environment in Gulf Coast petroleum exploration from paleoecology and related stratigraphy. Gulf Coast Association of Geological Societies, 16 : 119-129. 
تحليل الأحفوريات الحجرية من الحجر الجيري في منطقة بونجوميمي بناء على محتوى إحفوريات المنخريات القاعية ، مقاطعة كورونتالو ، إندونيسيا

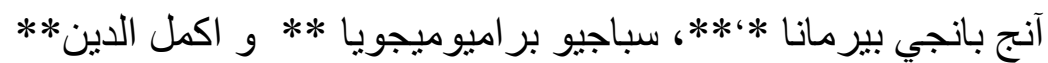

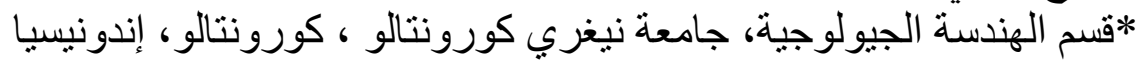

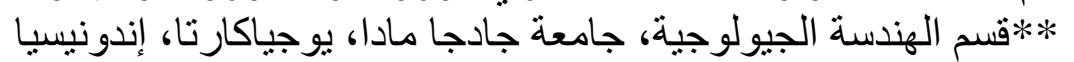

تأريخ الاستلام: 2019/07/29، تأريخ القبول: 2019/12/08، تأريخ النشر: 2020/06/24

الخلاصة

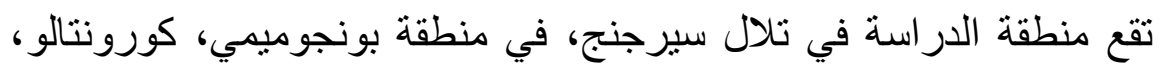

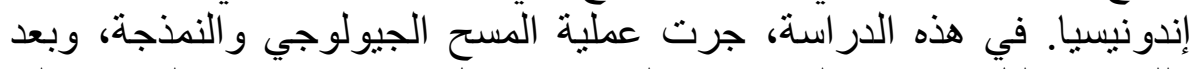

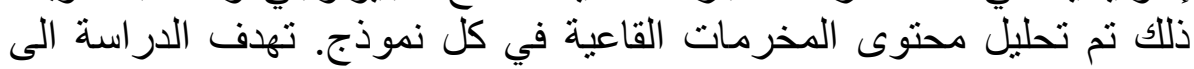

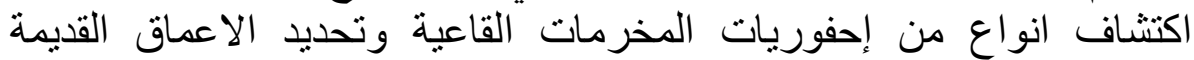

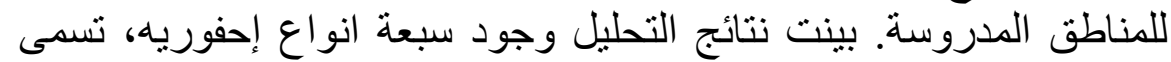
،Stelligerum astrononion ‘Ammomassilina alveoliniformis Praeglobobulimina 'Nonion fabum 'Haynesia germanica Saccorhiza ramose g Rhabdammina discreata ‘ovata

استناداً الى محتوى إحفوريات المخرمات القاعية، حدد العمق القديم على انه

الرف المتوسط الى الخارجي في بونجوميمي 1، بينما في بونجوريمي التئ 2 و 3 هو الرف المتوسط. 